\title{
Ellipsis
}

2021

\section{They Crept Care}

Jeremy Trager

University of New Orleans

Follow this and additional works at: https://scholarworks.uno.edu/ellipsis

\section{Recommended Citation}

Trager, Jeremy (2021) "They Crept Care," Ellipsis: Vol. 46, Article 18.

DOI: https://doi.org/10.46428/ejail.46.18

Available at: https://scholarworks.uno.edu/ellipsis/vol46/iss1/18

This Poetry is brought to you for free and open access by the Department of English and Foreign Languages at ScholarWorks@UNO. It has been accepted for inclusion in Ellipsis by an authorized editor of ScholarWorks@UNO. For more information, please contact scholarworks@uno.edu. 
They crept care-

fully away, inspiring new airs through the dust$y$ clefts of wings that had been detached and stored in drawers.

They shake off layers of artifice, painted on by faceless maestros - lethargy averted! Cocoons dissolve on spits over twigs \& coal.

They will touch all of the webs, dissecting all of the skins and cul-desacs and barrels full of fleshbounce into jamb, bray together.

They will free all inhibitions long since deferredmake arbitrary the contractions of dictation and demand.

They will softly blow away to farthest reaches; they will soar like doves past the last of the broken clocks. 